\title{
Mapping the body distribution of pain perception in fibromyalgia
}

\author{
Mapeamento da distribuição corporal da dor na fibromialgia
}

\section{Rodrigo Pegado de Abreu Freitas ${ }^{1}$, Maria Helena Constantino Spyrides ${ }^{2}$, José Guilherme da Silva Santa Rosa ${ }^{3}$, Ranulfo Fiel Pereira Pessoa de Carvalhó, Maria Bernardete Cordeiro de Sousa 5}

\section{RESUMO}

Introdução. Fibromialgia é uma síndrome crônica caracterizada por perda da funcionalidade e dor crônica generalizada. Objetivo. Objetivamos criar uma representação virtual da distribuição da dor em pacientes com fibromialgia. Método. Foram recrutados 50 indivíduos, com idade entre 32-71 anos, que atenderam os critérios do Colégio Americano de Reumatologia (ACR-1990) para diagnostico da fibromialgia e 42 voluntários saudáveis. A algometria foi realizada nos 18 pontos identificados pelo ACR, avaliando o limiar e tolerância à dor quantificada em $\mathrm{kg} / \mathrm{cm} 2$. A funcionalidade foi avaliada pelo Questionário de Impacto da Fibromialgia (FIQ). A diferença em porcentagem foi utilizada para ampliar a parte do corpo correspondente no grupo fibromialgia pelo software 3D-MAX ${ }^{\oplus}$. Resultados. Observamos diferença significativa entre o FIQ $(\mathrm{p}<0,0001)$, limiar (fibromialgia $1,8 \pm 0,4$; controle $4,7 \pm 1,2$ ) e tolerância à dor (fibromialgia $2,52 \pm 0,5$; controle $5,91 \pm 1,5)$ entre os grupos $(\mathrm{p}<0,0001)$. A representação corporal da dor no grupo fibromialgia difere do controle, mostrando que o aumento da percepçáo da dor ocorre principalmente nos braços, cervical, tórax, glúteos e joelhos. Conclusáo. É possível criar uma imagem virtual da dor em pacientes com fibromialgia através da algometria, podendo contribuir para a construção de uma representação específica da dor desta síndrome e para uma melhor gestão clínica e diagnóstica.

Unitermos. Fibromialgia, Pontos-Gatilho, Medição da Dor, Percepçâo da Dor.

Citação. Freitas RPA, Spyrides MHC, Rosa JGSS, Carvalho RFPP, Sousa MBC. Mapeamento da distribuição corporal da dor na fibromialgia.

\begin{abstract}
Background. Fibromyalgia is a syndrome characterized for persistent and debilitating disorder marked by chronic widespread pain. Objective. We aim to create a virtual body representation of peripheral pain to pressure in fibromyalgia patients. Method. Fifty adult subjects, aged 32-71 years, who fulfill the American College of Rheumatology (ACR) criteria for fibromyalgia and forty-two healthy volunteers, were recruited. Pain sensitivity was performed on the 18 points identified by ACR. Algometry was carried out to record threshold and tolerance to pain quantified in $\mathrm{kg} / \mathrm{cm} 2$. Functionality was evaluated by Fibromyalgia Impact Questionnaire (FIQ). Differences in percent were used to enlarge the correspondent body part in fibromyalgia group using a 3D MAX ${ }^{\circledast}$ Software. Results. Significant difference between FIQ $(p<0.0001)$, pain threshold (fibromyalgia 1.8 \pm 0.4 ; control $4.7 \pm 1.2$ ) and tolerance (fibromyalgia $2.52 \pm 0.5$; control 5.91 \pm 1.5 ) was found between the groups $(p<0.0001)$. The body pain representation in fibromyalgia group is different than control, showing that pain perception increases is mainly in cervical, thoracic, arms, gluteus and over the knees. Conclusion. It is possible to create a virtual body pain image of fibromyalgia using algometry. This may contribute to build a specific body representation of this syndrome and to contribute to better information for clinical management and diagnosis.
\end{abstract}

Keywords. Fibromyalgia, Trigger Points, Pain Measurement, Pain Perception.

Citation. Freitas RPA, Spyrides MHC, Rosa JGSS, Carvalho RFPP, Sousa MBC. Mapping the body distribution of pain perception in fibromyalgia.
Trabalho realizado no Hospital Universitário Onofre Lopes e na Clínica Escola de Fisioterapia da Universidade Potiguar, Natal-RN, Brasil.

\footnotetext{
1.Fisioterapeuta, Doutor, Professor do Curso de Fisioterapia da UFRN, Natal$-\mathrm{RN}$, Brasil.

2.Estatística, Doutora, Professora do Departamento de Estatística da UFRN, Docente dos Programas de Pós-graduação em Ciências Climáticas e do Programa de Pós-graduaçáo em Demografia da UFRN, Natal-RN, Brasil.

3.Analista de Sistemas, Doutor , Coordenador do Programa de Pós-Graduação em Design da UFRN, Natal-RN, Brasil.

4.Fisioterapeuta, Mestre, Professor do Curso de Fisioterapia da Universidade Potiguar, Mossoró-RN, Brasil.

5.Médica, Doutora, Professora Titular do Instituto do Cérebro, Docente dos Programas de Pós-graduação em Ciências da Saúde e Psicobiologia, UFRN, Natal-RN, Brasil.
}

Endereço para correspondência: Rodrigo PA Freitas

Department of Physiology Postgraduate Program in Psychobiology Federal Universityof Rio Grande do Norte Av Sen Salgado Filho, 3000 - Lagoa Nova CEP 59075-000, Natal-RN, Brazil Tel.: +558432153409 E-mail: rodrigopegado@gmail.com

Original

Recebido em: 05/08/13

Aceito em: 02/06/14

Conflito de interesses: não 


\section{INTRODUCTION}

Fibromyalgia is a non-inflammatory musculoskeletal chronic syndrome of unknown etiology and is characterized for persistent and debilitating disorder that can have a negative effect on people's lifes, affecting their capacity to work and engage in everyday activities, as well as their relationships with family, friends, and employers ${ }^{1,2}$. This condition is marked by chronic widespread pain and frequently associated symptoms including fatigue, sleep disturbances, cognitive dysfunction, and depressive episodes3. Patients with fibromyalgia display diffuse hyperalgesia (heightened pain responses to normally painful stimuli) and/or allodynia (pain responses to normally nonpainful stimuli). Such responses suggest that these individuals have a fundamental problem with pain or sensory processing rather than an abnormality confined to the region of the body where pain is experienced $^{3,4}$.

Many patients course with a set of symptoms that focus the presence of the central nervous system (CNS) as a protagonist and it is probable that the neurobiological changes found in the syndrome have its etiology in this system ${ }^{5}$. Until a decade, fibromyalgia and other idiopathic chronic pain conditions had a tenuous scientific argument. However, within a relatively short time, innovations in experimental tests of pain assessment, imaging techniques and immunogenetics have led to major advances in understanding the symptoms5,6. Great advances to understanding the fibromyalgia occurred after investigators found that this condition was not caused by peripheral injury or inflammation in muscles or tendons, focusing now on the study of central neurological component ${ }^{5-7}$. Authors described an abnormality in the central pain processing system, resulting in central amplification of pain signals ${ }^{7,8}$. The persistence of nociceptive receptors in peripheral tissue may lead to plastic alterations in the CNS, causing central amplification and an increase in pain sensitivity ${ }^{7,8}$.

Smythe showed a plastic body image in general population and a much greater representation of the painful region at several levels of neural representation in chronic pain syndromes like fibromyalgia'. Melzac attribute the symptoms observed in fibromyalgia to central neural mechanisms, but in the context of his neuroma- trix theory of pain ${ }^{10}$. He proposes that the symptoms of chronic pain syndromes such as fibromyalgia arise from the output patterns of the body-self neuromatrix, which activate perceptual, homeostatic, and behavioral progra$\mathrm{ms}$. The neural pattern is generated by the neuromatrix, which itself is genetically determined and influenced by sensory experiences. Melzack suggests that pain is a product of this pattern of activity rather than arising direct from sensory input. Maybe one factor that may influence Melzack's neuromatrix is a vulnerability to detecting or responding to sensory-motor conflict ${ }^{11}$.

A recent study indicates that body image is disturbed in patients with fibromyalgia when compared to control subjects ${ }^{12}$. It would be useful to consider the relationship of the body image disturbance with level of pain, impact of the disease, and quality of life ${ }^{12}$. Mapping the distribution of body pain in fibromyalgia patients may contribute to better information for clinical management in decreasing fibromyalgia symptom.

So, in disorders such as fibromyalgia, where the extent and intensity of the pain complaint often exceeds our capability for objective verification using current diagnostic technology readily available in the clinic, could we build a body pain image in fibromyalgia patients? We aim to create a fibromyalgia body representation of pain using a peripheral evaluation by algometry and visualize the most sensitive points of pain threshold and tolerance.

\section{METHOD}

\section{Participants}

A cross-sectional observational study sampling strategy was applied. Subjects who conformed to the diagnostic criteria for fibromyalgia ${ }^{13}$ were recruited over a 1-yr period from Medical Clinic of the Onofre Lopes University Hospital or attended in the Physiotherapy Clinic at the Universidade Potiguar, Natal, Brasil. The Research Ethics Committee of the Federal University of Rio Grande do Norte approved all the procedures described in this report (274/2010). Informed consent was obtained from all subjects, and the study protocols according to the ethical guidelines.

Fifty adult subjects, aged 32-71 years, who met the 1990 American College of Rheumatology (ACR) criteria ${ }^{13}$ for fibromyalgia were recruited. The control group 
consisted of forty-two healthy volunteers randomly chosen from hospital personnel and teachers.

The inclusion criteria adopted, were: a) medical diagnosis of fibromyalgia; b) ability to understand the study objective and answer the questions; c) not participating in physical therapy or rehabilitation programs in the three previous months. The control (CT) group met all the inclusion criteria except diagnosis of fibromyalgia and absence of both rheumatic and endocrinal disease. Exclusion criteria for both groups were: a) proven cognitive deficit, such as dementia; b) physical and/or organic difficulties, when these compromised questionnaire application and analgesic tests; c) endocrine, rheumatic and/or autoimmune diseases including chronic fatigue syndrome, chronic pelvic pain, atypical depression, irritable bowel syndrome, rheumatoid arthritis, gout and lupus; d) use of corticosteroids, analgesics and anti-inflammatory drugs. All fibromyalgia group patients had been diagnosed as having symptoms of fibromyalgia but no other concurrent condition, specifically no neurological illness that may have affected their proprioception and none had asymmetrical visible disfigurement on their upper or lower limbs.

Subjects were also asked if at last two weeks they had suffered any stressful experiences over that period, such as quarrels or receiving bad news, or if they had engaged in intense physical activity.

\section{Evaluation of pain sensitivity and symptoms of fi- bromyalgia}

Algometry was carried out to record pain threshold and pain tolerance to pressure. Eighteen tender points were marked with a demographic pencil and assessed while patients were in an orthostatic position, with their feet slightly separated. Pain sensitivity tests were performed on the 18 points identified by $\mathrm{ACR}^{14}$. This was done perpendicular to the skin at 5 to 10 second intervals by the same qualified examiner. A pressure algometer was used (Pain Diagnostics and Thermography ${ }^{\circ}$, Great Neck, NY, USA), through a 1-cm diameter rubber extremity. Pain threshold and tolerance to pressure were quantified in $\mathrm{kg} / \mathrm{cm}^{2}$. The examiner positioned the rubber point above the area to be examined and gradually increased the pressure by $1 \mathrm{~kg} / \mathrm{cm}^{2}$ per second. The pain threshold was measured when the patient said "I'm starting to feel pain". To measure tolerance to pain, the patient was asked to bear the maximum amount of pressure from the algometer and use the phrase "Stop, I cannot take anymore" when they were no longer able to do so. Patients were asked to use these exact phrases for total standardization of the test.

The functional status was evaluated using the Brazilian version of the Fibromyalgia Impact Questionnaire $(\mathrm{FIQ})^{15}$. It is a self-administered questionnaire that measures functional aspects of the patient over the last few weeks. It contains three Likert scale type questions (levels of response) and seven visual analog questions. All the scales vary from 1 to 10 and a high score indicates negative impact and more severe symptoms. The total FIQ score is graded from 1 to 100 points. Higher scores are related to greater impact of the disease on the patients' functionality and a corresponding reduction in their quality of life $e^{15,16}$. It was used only to characterize the functionality between both groups.

\section{Statistical analysis}

Statistical analyses were developed using 6 software that is available at http://www.r-project.org/, as well as GraphPad Prism 5 (GraphPad Software Inc. 2009). Quantitative parameters were statistically described by mean and standard deviation (SD). The first step of statistical analysis was to test the normal patterns using the Shapiro-Wilk test. The unpaired t test was used for inter-group parametric analysis. The Mann Whitney test was used when comparing inter-group non-parametric means. We used Spearman for correlation of pain threshold and pain tolerance in fibromyalgia group. The P-value considered was $\leq 0.05$ for statistically significant results.

It was chosen a visual representation of the results obtained through the body representation graph. In order to properly represent pain levels among body representation regions and between groups, relative differences in pain tolerance between control vs. fibromyalgia group, in percent, were determined, taking normal group as baseline. Such percent was used to enlarge the correspondent body part in fibromyalgia homunculus. By doing this, large body representation parts in fibromyalgia group represent a more painful region than the normal 
group.

We worked with a $3 \mathrm{D} \mathrm{MAX}^{\bullet}$ software image warping system that uses biometric data based on real body shapes, instead of simply stretching or compressing images of bodies. This technique also allows individual body parts to be altered separately, so we can determine whether a specific body part has an overestimated pain sensibility related to others. The program works by creating a series of templates for each body part at different points. Therefore, this graphical representation allows easy understanding and communication of the results obtained, enhancing ability to detect and comprehend variations between patients with difference in etiology of peripheral pain. It is a mnemonic tool as well, since larger parts are easily remembered and might help to build a typical image for fibromyalgia patients who would help in reinforce the diagnostic hypothesis.

\section{RESULTS}

All patients from the fibromyalgia and control groups underwent pain evaluation and questionnaires. A significant difference was found on analysis of FIQ scores between the two groups $(\mathrm{p}<0.0001$; Table 1$)$. The fibromyalgia group showed a decrease in pain threshold and tolerance to pressure, with higher algesic sensitivity. There was a significant difference between the means for pain threshold (fibromyalgia $1.8 \pm 0.4$; CT $4.7 \pm 1.2$ ) and tolerance to pain (fibromyalgia $2.52 \pm 0.5$; CT $5.91 \pm 1.5$ ) between the two groups $(\mathrm{p}<0.0001$; Table 1$)$. Table 2 illustrates the proportion of pain threshold and tolerance of 18 points evaluated. A strong positive correlation between pain threshold and pain tolerance $(r=0.983$; $\mathrm{p}<0.0001)$ was described in Figure 1.

Artist's impression of body representation of pain in control group was performed (Figure 2). There was significant distortion of the pain points evaluated with algometry, making large swollen areas in the body representation of pain tolerance in fibromyalgia group (Figure 3). The body representation showed greatest areas including cervical, thoracic, arms and over the knees.

\section{DISCUSSION}

In this study, we investigated the differences in body pain sensibility between fibromyalgia patients and matched healthy controls during application of pressure pain threshold and tolerance and show a graph in the human form of a pain homunculus. Through the analysis of numerical data it was possible to build a body representation of pain by the percentage difference between each of the 18 points evaluated. The results revealed that healthy controls had higher pain threshold and tolerance to pressure compared to fibromyalgia patients in all of eighteen points. Most fibromyalgia patients complain of local pains at the shoulders, arms, thighs and lower back, and pain originating from these body areas appears to play an important role in overall clinical conditions $s^{3,12}$. Understanding pain neurobiology provides a framework for more effective management of chronic pain such as fibromyalgia. These patients may have painful conditions that persist over years and is presented as the major symptom of the syndrome.

In normal pain processing, the perception of pain involves two main groups of neural pathways: ascending and descending pathways ${ }^{8}$. Peripheral nerves transmit sensory signals, including nociceptive stimuli to the spinal cord for transmission via the ascending nociceptive pathway to the brain for processing. The descending pain modulatory pathways send both facilitatory and inhibitory signals from the encephalon to the spinal cord and to the periphery, either increasing or decreasing the "volume control" on incoming nociceptive signals reaching the brain. Patients with fibromyalgia seem to have these two pain pathways operating abnormally, resulting in central amplification of pain signals ${ }^{17,18}$. It is equally clear that cognitive factors (catastrophizing) and psycho-

Table 1

Comparison of patient conditions.

\begin{tabular}{lccc}
\hline \multicolumn{4}{c}{ Groups } \\
\hline Variables & $\begin{array}{c}\text { Fibromyalgia } \\
(\mathrm{N}=50)\end{array}$ & $\begin{array}{c}\text { Control } \\
(\mathrm{N}=42)\end{array}$ & Value-p \\
\hline Age $^{\mathrm{b}}$ & $52.6 \pm 8$ & $48.3 \pm 9$ & -- \\
FIQ $^{\mathrm{b}}$ & $68.8 \pm 16.4$ & $18.1 \pm 12.3$ & $<0.0001$ \\
Pain Threshold $^{\mathrm{a}}$ & $1.8 \pm 0.4$ & $4.7 \pm 1.2$ & $<0.0001$ \\
Pain Tolerance $^{\mathrm{a}}$ & $2.52 \pm 0.5$ & $5.91 \pm 1.5$ & $<0.0001$ \\
\hline
\end{tabular}

Mean values and standard deviation (+SD). a Calculated with unpaired $t$ test. ${ }^{b}$ Calculated with Mann-Whitney nonparametric test. Pressure pain threshold and pain tolerance in $\mathrm{kg} / \mathrm{cm}^{2}$. 
Table 2

Statistics for the construction of the fibromyalgia body representation of pain: percentage differences between normal and patients with fibromyalgia.

\begin{tabular}{|c|c|c|c|c|c|c|}
\hline \multirow[b]{2}{*}{ Tender Point } & \multicolumn{3}{|c|}{ Pain Threshold } & \multicolumn{3}{|c|}{ Pain Tolerance } \\
\hline & Control & Fibromyalgia & $\%$ & Control & Fibromyalgia & $\%$ \\
\hline R Low Cervical & 2.54 & 1.62 & 36.21 & 3.40 & 2.25 & 33.72 \\
\hline L Low Cervical & 2.67 & 1.52 & 43.15 & 3.26 & 2.01 & 38.50 \\
\hline R Second Rib & 3.25 & 1.23 & 62.13 & 4.01 & 1.70 & 57.63 \\
\hline L Second Rib & 3.32 & 1.22 & 63.36 & 4.12 & 1.72 & 58.34 \\
\hline R Lat Epicondyle & 4.26 & 1.63 & 61.82 & 5.41 & 2.27 & 58.13 \\
\hline L Lat Epicondyle & 4.78 & 1.67 & 65.00 & 6.15 & 2.35 & 61.76 \\
\hline R Knee & 5.79 & 2.44 & 57.88 & 7.39 & 3.09 & 58.24 \\
\hline L Knee & 6.28 & 2.66 & 57.65 & 7.69 & 3.29 & 57.25 \\
\hline L Occiput & 3.75 & 1.54 & 58.85 & 4.56 & 2.06 & 54.78 \\
\hline R Occiput & 3.93 & 1.44 & 63.34 & 4.83 & 1.95 & 59.70 \\
\hline L Trapezius & 4.80 & 1.70 & 64.56 & 5.93 & 2.36 & 60.24 \\
\hline $\mathrm{R}$ Trapezius & 4.90 & 1.68 & 65.81 & 6.02 & 2.23 & 62.92 \\
\hline L Supraspinatus & 5.94 & 2.16 & 63.66 & 7.49 & 2.85 & 61.98 \\
\hline R Supraspinatus & 5.90 & 2.03 & 65.66 & 7.07 & 2.85 & 59.74 \\
\hline L Gluteal & 6.14 & 2.38 & 61.26 & 7.62 & 3.00 & 60.67 \\
\hline R Gluteal & 6.29 & 2.24 & 64.35 & 7.71 & 2.99 & 61.24 \\
\hline L Greater T & 5.85 & 2.56 & 56.21 & 7.09 & 3.26 & 53.99 \\
\hline R Greater T & 5.48 & 2.43 & 55.65 & 6.79 & 3.20 & 52.91 \\
\hline
\end{tabular}

$\mathrm{R}=$ right; $\mathrm{L}=$ left; Lat = lateral; Greater $\mathrm{T}=$ Greater Trochanter. Pressure pain threshold and pain tolerance in $\mathrm{kg} / \mathrm{cm}^{2}$.

logical factors (depression and anxiety) influence the central representation of pain $^{19}$ and the perception of pain is influenced by stressful situations and their mediators ${ }^{18}$. These factors were found in fibromyalgia ${ }^{19,20}$.

Overall clinical pain of fibromyalgia patients is dependent on local body pains ${ }^{21}$. This symptom is not uniformly distributed across the body but most prevalent in the shoulders, chest and lower back, corroborating with our findings. For these authors, the number of peripheral pain areas and the intensity of peripheral pain are better predictors of overall fibromyalgia pain than number of tender points (TPs), thus suggesting their relevance for fibromyalgia pathogenesis. But in all 18 points identified by $\mathrm{ACR}^{13}$ we found a significant difference when compared with health controls, possibly because they are regions where the pain sensation is present with more intensity.
Though our study works with pain threshold and tolerance to pressure, we can build other body representation using other painful conditions such as temperature (heat) or ischemic stimuli. In general, heat pain threshold and tolerance are significantly and strongly correlated with pain threshold and tolerance accessed via other modalities such as pressure ${ }^{22-24}$, indicating that these factors form part of a pain sensitivity phenotype $\mathrm{e}^{25}$. If, as these studies suggest, the laboratory-based assessment of individual differences in pain sensitivity has the potential to prospectively predict individual differences in acute clinical pain, chronic pain, and pain treatment response, then the ramifications and clinical applications of these findings are broad and quite important $\mathrm{t}^{25}$. The fibromyalgia body representation shows an increase in pain sensation in important areas related to daily activities.

In our study, the FIQ results describe a high sco- 


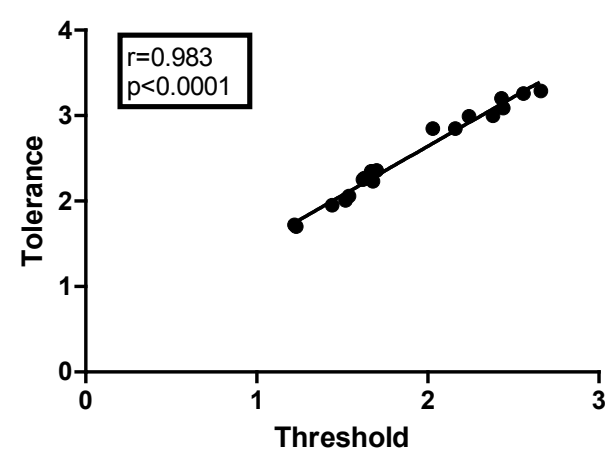

Figure 1.

Correlation between pain threshold and pain tolerance in fibromyalgia group. It was used the 18 points identified by $A C R^{13}$.

res indicating greater impact of the disease on the patients' functionality and a corresponding reduction in their quality of life ${ }^{26}$. Observing the areas of greatest sensitivity to pain, we can perform therapeutic conduct that enable the reduction of pain at these sites and improve patient's functionality. Our study showed a strong correlation between pain threshold and tolerance. Possibly we can improve these two parameters linearly after therapeutic intervention. The body representation of pain sensibility in fibromyalgia could be used to identify which peripheral areas are most affected by fibromyalgia.

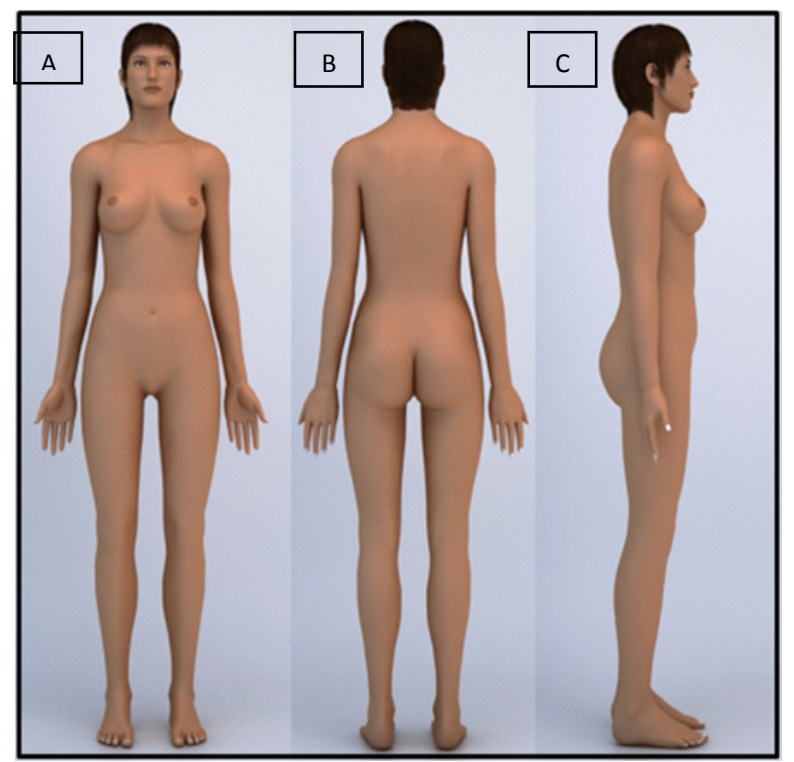

Figure 2.

Artist's impression of body representation of pain in control group. A: front; B: back; C: lateral.
Information regarding one's own pain sensitivity, relative to the general population, would presumably be available to individuals by observation and comparison of their responses and other's responses to common painful events such as injections, mild injuries, among others. In our work the perceptions of pain sensitivity in control group could be related to laboratory-derived measures of responses to standardized noxious stimuli ${ }^{25}$. These data were used to construct an image of normality shown by normal body representation. The graphical representation through a distorted human figure can help identify which body parts are more sensitive to pain in fibromyalgia. This technique can be used in clinical practice and contribute to a better therapeutic focus. Therefore, mapping the distribution of body pain in fibromyalgia may contribute to build a specific body representation of this syndrome and a better information for clinical management and diagnosis.

\section{KNOWLEDGEMENT}

The authors thank Victor Hugo (Student of Graduate School of Design, Department of Art, Federal University of Rio Grande do Norte, Natal-RN, Brazil).

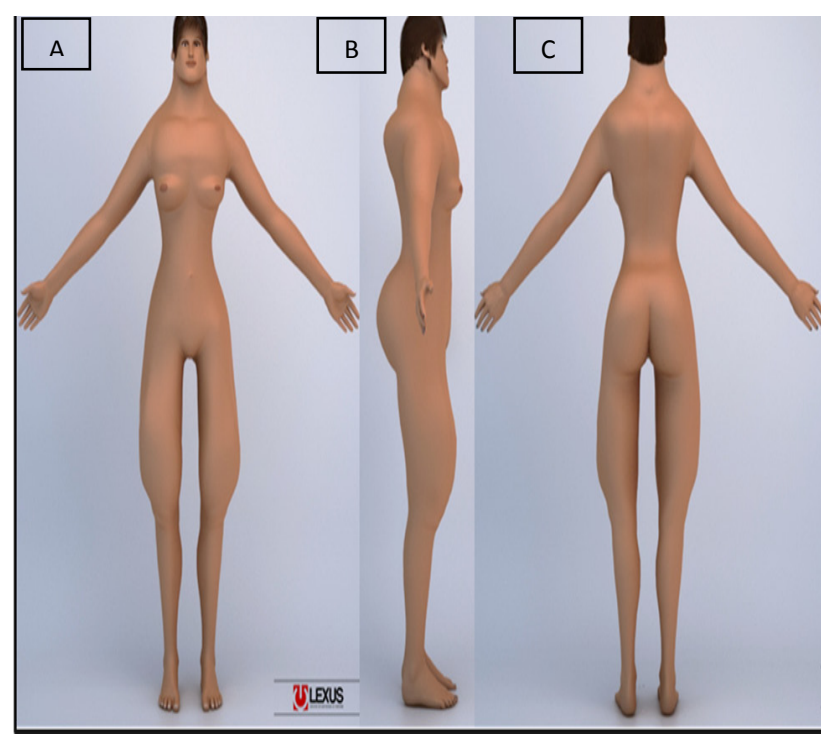

Figure 3.

Artist's impression of body representation of pain tolerance in fibromyalgia group. Large body representation parts represent a more painful region. A: front; B: lateral, C: back. 


\section{REFERENCES}

1.Bennett RM. Clinical Manifestations and Diagnosis of Fibromyalgia. Rheum Dis Clin North Am 2009;35:215-32. http://dx.doi.org/10.1016/j. rdc.2009.05.009

2.Arnold LM, Crofford LJ, Mease PJ, Burgess SM, Palmer SC, Abetz L, et al. Patient perspectives on the impact of fibromyalgia. Patient Educ Couns 2008;73:114-20. http://dx.doi.org/10.1016/j.pec.2008.06.005

3.Clauw DJ. Fibromyalgia: an overview. Am J Med 2009;122(12 Suppl):S3-13. http://dx.doi.org/10.1016/j.amjmed.2009.09.006

4.Bennett RM, Jones J, Turk DC, Russell IJ, Matallana L. An internet survey of 2,596 people with fibromyalgia. BMC Musculoskelet Disord 2007;8:27. http://dx.doi.org/10.1186/1471-2474-8-27

5.Clauw DJ. Fibromyalgia: update on mechanisms and management. J Clin Rheumatol 2007;13:102-9. http://dx.doi.org/10.1097/01. rhu.0b013e318053d9bc

6.Woolf CJ. Pain: moving from symptom control toward mechanism specific pharmacologic management. Ann Intern Med 2004;140:441-51. http:// dx.doi.org/10.7326/0003-4819-140-8-200404200-00010

7.Yunus MB. Central sensitivity syndromes: a new paradigm and group nosology for fibromyalgia and overlapping conditions, and the related issue of disease versus illness. Semin Arthritis Rheum 2008;37:339-52. http://dx.doi. org/10.1016/j.semarthrit.2007.09.003

8.Clauw DJ, Arnold LM, McCarberg BH, FibroCollaborative. The science of fibromyalgia. Mayo Clin Proc.2011;86:907-11. http://dx.doi.org/10.4065/ mcp.2011.0206

9.Smythe HA. Incarnations of fibromyalgia. J Rheumatol 2005;32:1422-5. 10.Melzack R. Evolution of the neuromatrix theory of pain. Pain Pract 2005;5:85-94. http://dx.doi.org/10.1111/j.1533-2500.2005.05203.x

11. McCabe CS, Cohen H, Blake DR. Somaesthetic disturbances in fibromyalgia are exaggerated by sensory motor conflict: implications for chronicity of the disease? Rheumatology (Oxford) 2007;46:1587-92. http://dx.doi. org/10.1093/rheumatology/kem204

12.Akkaya N, Akkaya S, Atalay NS, Balci CS, Sahin F. Relationship between the body image and level of pain, functional status, severity of depression, and quality of life in patients with fibromyalgia syndrome. Clin Rheumatol 2012;31:983-8. http://dx.doi.org/10.1007/s10067-012-1965-9

13. Wolfe F, Smythe HA, Yunus MB, Bennett RM, Bombardier C, Goldenberg DL, et al. The American College of Rheumatology 1990 criteria for the classification of fibromyalgia: report of the multicenter criteria committee. Arthritis Rheum 1990;33:160-72.

14.Okifuji A, Turk JD, Sinclair D, Starz TW, Marcus DA. A standardized manual tender point survey. Development and determination of a threshold point for identification of positive tender points in Fibromyalgia Syndrome. J Rheumatol 1997;24:377-83.

15.Marques AP, Santos AMB, Assumpçáo A, Matsutani LA, Lage LV, Pereira $\mathrm{CAB}$. Validation of the Brazilian version of the Fibromyalgia Impact Questionnaire (FIQ). Rev Bras Reumatol 2006;46:24-31. http://dx.doi.org/10.1590/ $\underline{\text { S0482-50042006000100006 }}$

16.Burckhardt CS, Clark SR, Bennett RM. The Fibromyalgia Impact Questionnaire: development and validation. J Rheumatol 1991;18:728-33.

17.Russell IJ, Larson AA. Neurophysiopathogenesis of fibromyalgia syndrome: a unified hypothesis. Rheum Dis Clin North Am 2009;35:421-35. http:// dx.doi.org/10.1016/j.rdc.2009.06.005

18. Williams DA, Clauw DJ. Understanding fibromyalgia: lessons from the broader pain research community. J Pain 2009;10:777-91. http://dx.doi. org/10.1016/j.jpain.2009.06.001

19.Gracely RH, Geisser ME, Giesecke T, Grant MA, Petzke F, Williams DA, et al. Pain catastrophizing and neural responses to pain among persons with fibromyalgia. Brain 2004;127:835-43. http://dx.doi.org/10.1093/brain/ $\underline{\text { awh098 }}$

20.Chrousos GP, Gold PW. The concepts of stress and stress system disorders: Overview of physical and behavioral homeostasis. JAMA 1992;267:1244-52. http://dx.doi.org/10.1001/jama.1992.03480090092034

21.Staud R, Vierck CJ, Robinson ME, Price DD. Overall fibromyalgia pain is predicted by ratings of local pain andpain-related negative affect-possible role of peripheral tissues. Rheumatology (Oxford) 2006;45:1409-15. http://dx.doi. org/10.1093/rheumatology/kel121

22.Bhalang K, Sigurdsson A, Slade GD, Maixner W. Associations among four modalities of experimental pain in women. J Pain 2005;6:604-11. http:// dx.doi.org/10.1016/j.jpain.2005.04.006

23.Petzke F, Clauw DJ, Ambrose K, Khine A, Gracely RH. Increased pain sensitivity in fibromyalgia: effects of stimulus type and mode of presentation. Pain.2003;105:403-13. http://dx.doi.org/10.1016/S0304-3959(03)00204-5

24.Hastie BA, Riley JL, III, Robinson ME, Glover T, Campbell CM, Staud R, Fillingim RB. Cluster analysis of multiple experimental pain modalities. Pain 2005;116:227-37. http://dx.doi.org/10.1016/j.pain.2005.04.016

25.Edwards RR, Fillingim RB. Self reported pain sensitivity: lack of correlation with pain threshold and tolerance. Eur J Pain 2007;11:594-8. http://dx.doi. org/10.1016/j.ejpain.2006.09.008

26. Helfenstein Junior M, Goldenfum MA, Siena CA. Fibromyalgia: clinical and occupational aspects. Rev Assoc Med Bras 2012;58:358-65. http://dx.doi. org/10.1590/S0104-42302012000300018 